\title{
Adaptation of biochemical composition and cell size to irradiance in two microalgae: possible ecological implications
}

\author{
Hervé Claustre, Jacques Gostan
}

CEROV, Station zoologique, UA 716, F-06230 Villefranche-sur-Mer, France

\begin{abstract}
Two marine microalgae (Haptophyceae), Hymenomonas elongata and Isochrysis galbana, were grown in turbidostats in order to investigate the influence of light intensity on cell volume and biochemical composition. At irradiance levels that saturated growth $\left(400 \mu \mathrm{E} \mathrm{m} \mathrm{m}^{-2} \mathrm{~s}^{-1}\right)$, the algae contained a high level of carbon compounds, especially soluble sugars. At the irradiance that limited growth $\left(25 \mu \mathrm{E} \mathrm{m}^{-2} \mathrm{~s}^{-1}\right)$ sugar pools were lower for the 2 algae and $H$. elongata decreased its volume by $25 \%$. In the transitional phase that followed a shift from $400 \mu \mathrm{E} \mathrm{m}^{-2} \mathrm{~s}^{-1}$ to $25 \mu \mathrm{E} \mathrm{m} \mathrm{m}^{-2} \mathrm{~s}^{-1}$ rates at which biochemical ratios reached stability differed for the 2 algae. Re-establishing high light intensity after a period under low light intensity influenced algal volume in $H$. elongata; this event followed a particular kinetic pattern that we attempt to explain on theoretical grounds. Results are discussed with regard to durations of irradiance perturbations that can occur in the sea.
\end{abstract}

\section{INTRODUCTION}

Natural phytoplankton populations are continuously subjected to changes in irradiance on a wide range of scales: seasonal, nycthemeral, tidal, and meteorological. Studying the effects of these fluctuations on the metabolism of autotrophic organisms may increase our knowledge concerning the relations between light intensity and primary production.

Steemann Nielsen \& Hansen (1959) showed that algae respond to variations in irradiance by modifying their photosynthesis vs irradiance relationships and the amplitude and speed of these modifications are species dependent (Jørgensen 1964). The adaptive nature of a response, such as maintenance of an optimum growth rate dependent on irradiance, becomes evident when a new steady state is reached (Steemann Nielsen \& Jørgensen 1968). Studies of P vs I relations have been numerous, whereas kinetic responses have been less intensely investigated. However, studies of kinetic responses are necessary to determine the adaptation rates of algae and to compare them with the time scale of oceanic forcing variables (Falkowski 1983, 1984, Post et al. 1984).

Photosynthetic rates, and thus irradiance, affect biochemical composition (Morris 1980, 1981, Redalje \&
Laws 1983, Terry et al. 1983) and the volume of cells (Prezelin \& Sweeney 1978, Falkowski \& Owens 1980 , Gallagher \& Alberte 1985). Both biochemical composition and volume of phytoplankton influence the in situ efficiency of the secondary production as well as the sinking rate of the algae. From an ecological point of view, variations induced by changes in irradiance call for more attention.

The purpose of this investigation is to obtain a better understanding of adaptations in biochemical composition and cell volume, resulting from a change in irradiance for 2 species of Haptophyceae, Hymenomonas elongata (Droop) Parke \& Green and Isochrysis galbana Parke. Adaptation of both algae was investigated in 2 ways: (1) amplitude of observed responses (static point of view), and (2) rate at which these responses occur (dynamic point of view). We have developed a simple model in order to explain the kinetics of $H$. elongata volume during the transient phase following a change in irradiance.

\section{MATERIALS AND METHODS}

Organisms and culture. Hymenomonas elongata and Isochrysis galbana cultures were grown at $18^{\circ} \mathrm{C}$ in $\mathrm{f} / 2$ 
medium (Guillard \& Ryther 1962), in a 2.5 I cylindrical glass turbidostat. Cell densities were monitored by fluorometry (Turner fluorometer, model 111), and kept constant by dilution controlled by a microcomputer (Fenaux et al. 1985). Biovolumes were stable within a $10 \%$ range when environmental conditions did not vary. Outflow of $\mathrm{NO}_{3}$ and $\mathrm{PO}_{4}$ never fell below 400 and $20 \mu \mathrm{g}$-at $\mathrm{l}^{-1}$, hence the culture was never nutrient limited.

Light was provided by fluorescent lamps (Sylvania Grolux). PAR (total photosynthetic available radiation) was measured with a spherical quantum meter (Biospherical, QSL-100). Two illuminations were used, one saturating $\left[\operatorname{PAR}(400)=400 \mu \mathrm{E} \mathrm{m}^{-2} \mathrm{~s}^{-1}\right]$, the other limiting $\left[\operatorname{PAR}(25)=25 \mu \mathrm{E} \mathrm{m} \mathrm{m}^{-2} \mathrm{~s}^{-1}\right]$. The 2 levels were adjusted by altering the number of lamps. Cell densities were kept low in order to minimize selfshading. When PAR was changed, the automatic dilution system was stopped for $2 \mathrm{~d}$. This was done for 2 reasons: (1) During the transient period following PAR modification, fluorescence of the culture was strongly affected and did not provide good estimates of algal biomass. Fluorescence could be used again (in the automatic mode) when the growth rate became stable. (2) For studying the kinetics of cellular compounds when PAR was modified, it was necessary to increase the frequency of sampling. But when PAR was low, the outflow was too slow (because growth rate and therefore dilution rate were low) to provide sufficient culture for all measurements required. Manual control of dilution was then necessary.

The period of time to reach growth stability is a function of the species concerned and perhaps also of the amplitude of PAR variation. With the 2 species investigated, $48 \mathrm{~h}$ were sufficient to reach the stability of fluorescence that permits estimating growth rate. Raps et al. (1983) report comparable results, whereas Perry et al. (1981) noted that 10 to $20 \mathrm{~d}$ were necessary for complete adaptation to very low light intensity $(4 \mu \mathrm{E}$ $\left.\mathrm{m}^{-2} \mathrm{~s}^{-1}\right)$.

Sampling and analysis. Table 1 lists the experimental procedure adopted in this study. At steady state, 1 sample was taken per day; during a transient phase, 5 samples were taken on the first day and 2 on the second day following a change in irradiance. For each sample, $150 \mathrm{ml}$ of outflow was subsampled, filtered onto glass fiber Whatman GF/C filters (precombusted at $500^{\circ} \mathrm{C}$ for $5 \mathrm{~h}$ ), and then stored at $-70^{\circ} \mathrm{C}$ until analysed.

Proteins $(\mathrm{Pr})$ were determined with $5 \%$ precision according to the method of Lowry et al. (1951), adapted by Malara \& Charra (1972a). Total sugars (St) were estimated with $3 \%$ precision according to Dubois et al. (1956) as adapted by Malara \& Charra (1972b). Soluble sugars (Ss) were analysed according to Dubois, after a double extraction at $50{ }^{\circ} \mathrm{C}$ in $0.4 \% \mathrm{HCl}$ with a precision of $10 \%$. After extraction (Bligh \& Dyer 1959), lipids were determined according to Barnes \& Blackstock (1973). Cellular carbon (C) and nitrogen (N) of Hymenomonas elongata were determined by combustion (CHN autoanalyser, Perkin Elmer), with $2 \%$ precision for $\mathrm{C}$ and $3.5 \%$ for $\mathrm{N}$. Chlorophyll a was calculated according to Jeffrey \& Humphrey (1975), after extraction in $90 \%$ acetone. Cellular caloric values were estimated as the sum of caloric equivalents for cellular protein $\left(4.19 \mathrm{ncal} \mathrm{pg}^{-1}\right.$ protein), total sugars $(4.2 \mathrm{ncal}$ $\mathrm{pg}^{-1}$ total sugar) and lipids ( $9.5 \mathrm{ncal} \mathrm{pg}^{-1}$ lipid) according to Prosser \& Brown (1961).

Cell density and cell size were determined with a 12 channel automatic particle size analyser (Hiac model PC 320, CMH-60 sensor). This counter sizes cells from the projection surface of algae measured by a photoelectric cell. The mean diameter of the population was calculated as:

$$
\mathrm{D}_{\mathrm{c}}=\Sigma\left(\mathrm{n}_{1} \mathrm{D}_{\mathrm{i}}\right) / \mathrm{N}
$$

Table 1. Hymenomonas elongata and Isochrysis galbana. Information on growth in a turbidostat. Vc: mean cellular volume; $\mathrm{N}$ : nitrogen; C: carbon; Pr: proteins; St: total sugars; Ss: soluble sugars; Li: lipids; Chla: chlorophyll a

\begin{tabular}{|c|c|c|c|c|c|}
\hline & \multicolumn{5}{|c|}{ H. elongata } \\
\hline & \multicolumn{2}{|l|}{$\operatorname{PAR}(400)_{1}$} & $\operatorname{PAR}(25)$ & \multicolumn{2}{|c|}{$\operatorname{PAR}(400)_{2}$} \\
\hline Time (h) & 236 & 48 & 120 & 48 & 145 \\
\hline \multirow[t]{3}{*}{$\begin{array}{l}\text { Variable } \\
\text { measured }\end{array}$} & $\begin{array}{l}\text { VC, N, C, Pr, } \\
\text { St, Ss, Li, Chla }\end{array}$ & $\mathrm{VC}, \mathrm{N}, \mathrm{C}$ & $\begin{array}{l}\text { Vc, N, C, Pr, } \\
\text { St, Ss, Chla }\end{array}$ & $V_{C}, N, C$ & $\begin{array}{l}\text { Vc, N, C, Pr, St, Ss, } \\
\text { Li, Chla }\end{array}$ \\
\hline & \multirow{2}{*}{\multicolumn{3}{|c|}{ I. galbana }} & & \\
\hline & & & & & \\
\hline Time (h) & 92 & 48 & 71 & & \\
\hline $\begin{array}{l}\text { Variable } \\
\text { measured }\end{array}$ & $\begin{array}{l}\text { Vc, PI, St, } \\
\text { Ss, Li, Chla }\end{array}$ & $\begin{array}{l}\text { Vc, Pr, St, } \\
\text { Ss, Li }\end{array}$ & $\begin{array}{l}\text { Vc, Pr, St, } \\
\text { Ss, Li, Chla }\end{array}$ & & \\
\hline
\end{tabular}


where $n_{1}=$ number of cells in channel $i_{;} D_{1}=$ average diameter of cells in the ith channel; $N=$ total number of cells. Since the cells of both species are spherical, mean volume $\left(D_{c}\right)$ was computed directly from Dc. Cell density and mean volume were estimated with 6 and $5 \%$ precision, respectively.

For investigating the rate of adaptation processes, we used the equation proposed by Falkowski (1980) to describe the kinetics of adaptation of cellular parameters:

$$
A_{t}=A_{f}+\left(A_{i}-A_{f}\right) \cdot e^{-k t}
$$

where $A_{t}=$ value of a cellular parameter at time $t ; A_{i}=$ initial value before PAR modifications; $A_{f}=$ final value when a new steady state is reached; $k$ = rate of adaptation process, assumed to be constant. Data were fitted according to the Marquardt algorithm (Conway et al. 1970).

Table 2. Hymenomonas elongata and Isochrysis galbana. Mean cellular volume $\left(\mathrm{Vc}_{i} \mu \mathrm{m}^{3} \mathrm{cell}^{-1}\right)$ at steady state for each irradiance Means $\pm \mathrm{SD}$; $\mathrm{n}$ : number of observations

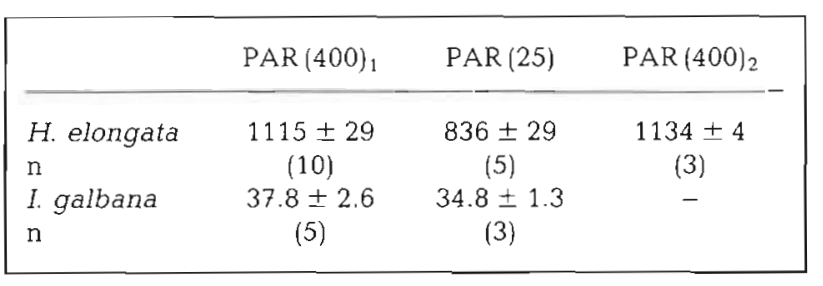
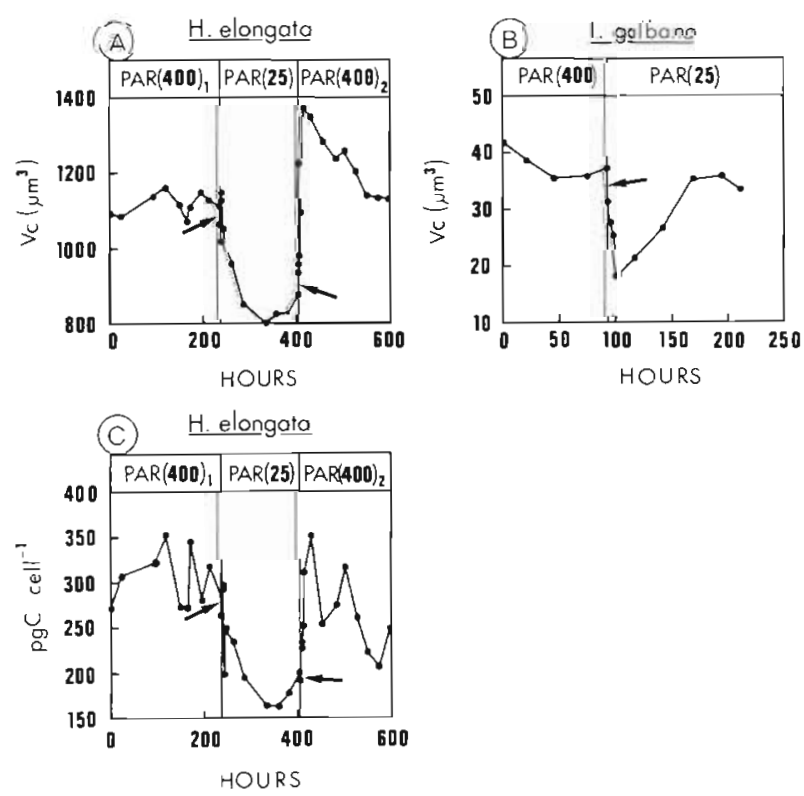

Fig. 1. Hymenomonas elongata and Isochrysis galbana. Changes in volume and cellular carbon in relation to irradiance. (A) $H$. elongata mean cellular volume; (B) $I$. galbana mean cellular volume; (C) $H$. elongata cellular carbon. Arrows: change in PAR

\section{RESULTS}

\section{Cell volume}

Under steady state conditions the cellular volume of Isochrysis galbana remained independent of PAR (Table 2). For Hymenomonas elongata mean $\mathrm{VC}_{\mathrm{C}}$ at PAR(400) (either first or second phase at this irradiance) was significatively different $(p<0.01)$ from $V_{C}$ at PAR(25). For both species the change from PAR(400) to PAR(25) was rapidly followed by a decrease in Vc (Fig. 1). The initial value [at PAR(400)] was re-attained within 60 to $70 \mathrm{~h}$ in $I$. galbana; in $H$. elongata it was reached only after the PAR(400) regime was re-established. Using Eq. (2) we estimated that the rate of adaptation of $H$. elongata to a reduction in PAR was $0.043 \mathrm{~h}^{-1}$ (Fig. 2A).

However, when the irradiance was increased to PAR(400) Falkowski's equation could not be fitted to the experimental data as the adaptation process did not follow first order kinetics.

\section{Biochemical compounds}

Protein cellular pools in Isochrysis galbana were $25 \%$ larger at PAR(400) than at PAR(25) (Table 3). However, this difference was not significant $(p>0.05)$,
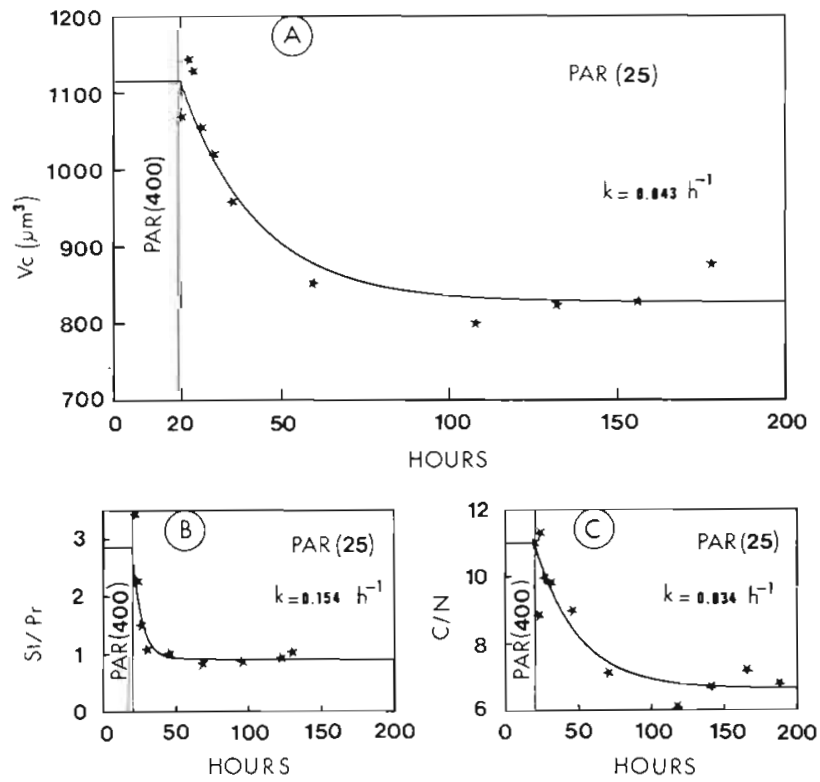

Fig. 2. Hymenomonas elongata and Isochrysis gälbana. Fit of Eq. (1) to the kinetics of volume changes and biochemical ratios during transient state following passage from PAR(4.00) to PAR(25). (A) Mean cellular volume of $H$. elongata; (B) ratio $\mathrm{St} / \mathrm{Pr}$ for $I$. galbana; (C) ratio $\mathrm{C} / \mathrm{N}$ for $H$. elongata. $\mathrm{K}=$ kinetic constant of Eq. (2) 
indicating that protein metabolism may not be strongly affected by a reduction in PAR. Nitrogen and protein concentrations in Hymenomonas elongata, normalized to algal biovolume, were different at both irradiances. Variations in the nitrogen and protein pools were complemented by variations in cell volume $135 \%$ in both cases) so that these changes at PAR(25) were dependent on a change in $V_{C}$ and not in protein metabolism.

For both algae, low irradiances induced an increase in chlorophyll content by a factor of about 3 (Table 3). On a biovolume basis Isochrysis galbana chlorophyll content is higher than in Hymenomonas elongata. Total sugar pool (St) was about $70 \%$ lower at PAR(25) than at PAR(400) (Table 3). However, the Ss/ St ratio (Table 4) was close to 0.70 for the 2 algae at
PAR(400) and became nil for $H$. elongata at PAR(25) while it did not change $(0.73)$ for I. galbana. In both algae, lipid pools seem to be less affected by PAR reduction than carbohydrates (Table 3), but there was a higher proportion of lipids relative to proteins in $I$. galbana ( $\mathrm{Li} / \mathrm{Pr}$ ratios, Table 4) compared to $H$. elongata.

Cellular caloric content (normalized to biovolume) was remarkably similar in both algae (Table 4) at PAR(400) (if we consider the first exposure to this irradiance for Hymenomonas elongata) and at PAR(25). For $H$. elongata, the lower cellular caloric content (normalized to biovolume) obtained for the second exposure at PAR(400) is complemented by the change in carbon compounds. In fact, $200 \mathrm{~h}$ after the re-establish-

Table 3. Hymenomonas elongata and Isochrysis galbana. Mean biochemical composition at steady state for each irradiance. $\mathrm{A}: \mathrm{pg}$ cell ${ }^{-1} ; \mathrm{B}: 10^{-3} \mathrm{pg} \mu \mathrm{m}^{-3}$. Means $\pm \mathrm{SD} ; \mathrm{n}$ : number of observations

\begin{tabular}{|c|c|c|c|c|c|c|}
\hline & & \multicolumn{3}{|c|}{ H. elongata } & \multicolumn{2}{|c|}{ I. galbana } \\
\hline & & $\operatorname{PAR}(400)_{1}$ & PAR (25) & $\operatorname{PAR}(400)_{2}$ & $\operatorname{PAR}(400)$ & $\operatorname{PAR}(25)$ \\
\hline & $\mathrm{A}$ & $27.5 \pm 2.7$ & $26.1 \pm 2.1$ & $21.7 \pm 2.3$ & - & - \\
\hline$N$ & $\begin{array}{l}\mathrm{B} \\
\mathrm{n}\end{array}$ & $\begin{array}{c}24.7 \pm 2.1 \\
(10)\end{array}$ & $\begin{array}{c}31.6 \pm 1.7 \\
(5)\end{array}$ & $19 \pm 2$ & - & - \\
\hline & $A$ & $302.4 \pm 30.3$ & $180 \pm 17.4$ & $225.6 \pm 21.2$ & - & - \\
\hline C & $\begin{array}{l}\mathrm{B} \\
\mathrm{n}\end{array}$ & $\begin{array}{c}270.8 \pm 24.4 \\
(10)\end{array}$ & $\begin{array}{c}214.8 \pm 13.9 \\
(5)\end{array}$ & $199 \pm 19.3$ & - & - \\
\hline PI & $\begin{array}{l}\mathrm{A} \\
\mathrm{B} \\
\mathrm{n}\end{array}$ & $\begin{array}{c}116.5 \pm 14.3 \\
104.4 \pm 10.5 \\
(7)\end{array}$ & $\begin{array}{c}115.9 \pm 11.3 \\
141.6 \pm 11.7 \\
\text { (3) }\end{array}$ & $\begin{array}{c}93.2 \pm 12 \\
82 \pm 10.4 \\
\text { (3) }\end{array}$ & $\begin{array}{c}2.52 \pm 0.28 \\
65.8 \pm 4.97 \\
(4)\end{array}$ & $\begin{array}{c}1.96 \pm 0.11 \\
56.4 \pm 5.39 \\
\text { (3) }\end{array}$ \\
\hline St & $\begin{array}{l}\mathrm{A} \\
\mathrm{B} \\
\mathrm{n}\end{array}$ & $\begin{array}{c}362.4 \pm 49.8 \\
324.7 \pm 36.8 \\
(7)\end{array}$ & $\begin{array}{r}99.8 \pm 15.6 \\
121.3 \pm 17.6 \\
(3)\end{array}$ & $\begin{array}{c}259.6 \pm 43.5 \\
229.3 \pm 39 \\
(3)\end{array}$ & $\begin{array}{r}6.68 \pm 0.8 \\
174.5 \pm 19.9 \\
(4)\end{array}$ & $\begin{array}{l}1.88 \pm 0.24 \\
54.3 \pm 8.7\end{array}$ \\
\hline Ss & $\begin{array}{l}\mathrm{A} \\
\mathrm{B} \\
\mathrm{n}\end{array}$ & $\begin{array}{c}254.5 \pm 62.9 \\
226 \pm 53 \\
\text { (5) }\end{array}$ & $\begin{array}{c}0 \\
0 \\
(3)\end{array}$ & $\begin{array}{c}185.3 \pm 24.9 \\
163.3 \pm 22.8 \\
\text { (3) }\end{array}$ & $\begin{array}{c}5.02 \pm 1.22 \\
129.7 \pm 24.3 \\
(4)\end{array}$ & $\begin{array}{c}1.36 \pm 0.04 \\
39.3 \pm 0.5 \\
(3)\end{array}$ \\
\hline $\mathrm{Li}$ & $\begin{array}{l}\mathrm{A} \\
\mathrm{B} \\
\mathrm{n}\end{array}$ & $\begin{array}{c}40.6 \pm 9.17 \\
36.7 \pm 8.3 \\
(7)\end{array}$ & $\begin{array}{c}16.8 \pm 10.1 \\
20.5 \pm 12 \\
\text { (2) }\end{array}$ & $\begin{array}{c}29.5 \pm 10.9 \\
26 \pm 9.5 \\
(3)\end{array}$ & $\begin{array}{c}4.08 \pm 1.31 \\
107.5 \pm 36.8 \\
(4)\end{array}$ & $\begin{array}{c}2.90 \pm 0.67 \\
83.2 \pm 17.9 \\
\text { (3) }\end{array}$ \\
\hline Chla & $\begin{array}{l}A \\
B \\
n\end{array}$ & $\begin{array}{c}2.95 \pm 0.28 \\
2.62 \pm 0.23 \\
(6)\end{array}$ & $\begin{array}{c}7.69 \\
9.28 \\
(1)\end{array}$ & $\begin{array}{c}2.24 \\
1.97 \\
(1)\end{array}$ & $\begin{array}{c}0.162 \pm 0.015 \\
4.3 \pm 0.56 \\
\quad(2)\end{array}$ & $\begin{array}{c}0.505 \pm 0.054 \\
14.55 \pm 0.77 \\
(2)\end{array}$ \\
\hline
\end{tabular}

Table 4. Hymenomonas elongata and Isochrysis galbana. Biochemical ratios and caloric values at steady state

\begin{tabular}{|c|c|c|c|c|c|}
\hline & \multicolumn{3}{|c|}{ H. elongata } & \multicolumn{2}{|c|}{ I. galbana } \\
\hline & $\operatorname{PAR}(400)_{1}$ & $\operatorname{PAR}\{25\}$ & $\operatorname{PAR}(400)_{2}$ & $\operatorname{PAR}(400)$ & $\operatorname{PAR}(25)$ \\
\hline ncal. cell ${ }^{1}$ & 2388 & 1065 & 1849 & 77.36 & 44.37 \\
\hline ncal. $\mu \mathrm{m}^{-3}$ & 2.14 & 1.27 & 1.63 & 2.22 & 1.27 \\
\hline $\mathrm{C} / \mathrm{N}$ & 10.98 & 6.89 & 10.83 & - & - \\
\hline $\mathrm{St} / \mathrm{Pr}$ & 3.11 & 0.86 & 2.93 & 2.65 & 0.93 \\
\hline Ss/St & 0.70 & 0 & 0.72 & 0.75 & 0.73 \\
\hline $\mathrm{Li} / \mathrm{Pr}$ & 0.35 & 0.15 & 0.36 & 1.62 & 1.52 \\
\hline
\end{tabular}


ment of PAR(400), the pools of different carbon compounds (total sugars, soluble sugars, lipids and also carbon) in $H$. elongata did not recover their initial concentrations [Table 3: PAR $(400)_{1}$ vs PAR $(400)_{2}$ and Fig. 1C). Considering that cell volumes returned to their initial values, intracellular concentrations of carbon compounds were lower than the concentration initially measured at PAR(400).

Fig. 2B \& C show the fit of Eq. (2), after a reduction in $\mathrm{PAR}$, to $\mathrm{St} / \mathrm{Pr}$ and $\mathrm{C} / \mathrm{N}$ ratios of Isochrysis galbana and Hymenomonas elongata, respectively. The $\mathrm{C} / \mathrm{N}$ and St/ Pr ratios are comparable for 2 reasons: (1) nitrogenous pools did not vary, (2) the sugar pool, which is the more important, showed greater variation. The kinetic constants were significantly higher in I. galbana $\left(0.155 \mathrm{~h}^{-1}\right)$ $(\mathrm{p}<0.01)$ than in $H$. elongata $\left(0.034 \mathrm{~h}^{-1}\right)$.

\section{DISCUSSION}

\section{Cell volume}

The differences observed in mean cell volume (Vc) for Hymenomonas elongata at high and low irradiances have also been reported for other species, such as Scenedesmus obliquus (Senger \& Fleischhacker 1978), Skeletonema costatum (Falkowski \& Owens 1980, Gallagher \& Alberte 1985), and Dunaliella tertiolecta (Falkowski \& Owens 1980). At steady state, increase or decrease in $H$. elongata volume is associated with increase or decrease of the Ss/St ratio, whereas in Isochrysis galbana neither volume nor Ss/St ratio vary. Since the soluble sugar fraction is stored in the vacuole (Lee 1980), these observations suggest that, at steady state, the volume of both algae depends on the size of the soluble sugar vacuole

The rapid changes in volume of microalgae are under the control of 2 factors: (1) variation of internal ion concentration (Riisgård et al. 1980); (2) variation of low molecular weight metabolites of photosynthetic origin (A.hmad \& Hellebust 1985, Dor 1985, Reed \& Stewart 1985). For the crysophyceae Ochromonas malhamensis ca 70 to $80 \%$ of osmotic activity is due to an increase in a small carbohydrate (isofloridoside), whereas 20 to $30 \%$ is due to an increase in free amino acids or in $\mathrm{K}^{+}$(Aaronson 1980). For Hymenomonas elongata, kinetics of the change in $\mathrm{Vc}$ and $\mathrm{C} \mathrm{cell}^{-1}$ are similar, and both variables show an overshoot after the re-establishment of PAR(400). This similarity suggests that variations in cell volume are controlled by carbon metabolism. In order to test whether there is a relationship between Vc and cell photosynthetic rate, we used a model which simulates the transient photosynthesis of cells subjected to sudden increase in irradiance.

The initial steady state, at PAR(25), was calculated from production (P) per unit chlorophyll a (B) vs irradiance (I), as proposed by Talling (1957) and adapted by Platt et al. (1977):

$$
\mathrm{P}^{\mathrm{B}}=\frac{\mathrm{P}_{\text {max }}^{\mathrm{B}} \cdot \alpha^{\mathrm{B}} \mathrm{I}}{\left[\left(\mathrm{P}_{\mathrm{max}}^{\mathrm{B}}\right)^{2}+\left(\alpha^{\mathrm{B}} \cdot \mathrm{I}\right)^{2}\right]^{(1 / 2)}}
$$

where $\mathrm{P}^{13}{ }_{\max }=$ maximum normalized photosynthetic rate; $\alpha^{B}=$ initial slope of $\mathrm{P}^{\mathrm{B}}$ vs I curve. $\mathrm{P}_{\text {max }}^{\mathrm{B}}$ and $\alpha^{\mathrm{B}}$ were measured under the same conditions as in a previous experiment (Gostan unpubl.; Table 5). $\mathrm{P}^{\mathrm{B}}$ was then transformed into production by multiplying it by the cellular chlorophyll a content (Chla cell ${ }^{-1}$; Table 5).

Cell production following increase in irradiance was investigated according to the following hypothesis: $\mathrm{P}^{\mathrm{B}}{ }_{\text {max }}$ and Chla cell ${ }^{-1}$ vary with PAR modifications and follow a kinetic described by Eq. (2), as reported by Falkowski (1984) for Dunaliella tertiolecta. At the same time, $\alpha^{B}$ does not vary with PAR (Falkowski 1984). To illustrate this, Fig. 3 gives the combined influences of Chla cell ${ }^{-1}$ (Fig. 3A) and $\mathrm{P}_{\max }$ (Fig. 3B) on cellular production (Fig, 3C). Adaptation rates of Chla and $\mathrm{P}_{\text {max }}^{\mathrm{B}}$ are computed using Eq. (2) and are used to calculate cell production with Eq. (3). Values used in the simulations are given in Table 5. Fig. $3 \mathrm{C}$ shows that, just after the change in irradiance, Hymenomonas elongata reveals a transient maximum of $\mathrm{P}$ cell ${ }^{-1}$ (Curve 1) equivalent to that observed for $\mathrm{VC}$ and $\mathrm{C}$ cell $^{-1}$ (Fig. 1A \& C). The 2 kinetic constants of Chla and $\mathrm{P}^{\mathrm{B}}$ max used to simulate Curve 1 in Fig. $3 \mathrm{C}$ are identical $\left(0.04 \mathrm{~h}^{-1}\right.$; Table 5$)$. These values, being close to the adaptation constants of $\mathrm{VC}$ (Fig. 2A) and the C/N ratio (Fig. 2C), are therefore consistent with the metabolic rates of the cells. Thus the momentary cellular overproduction simulated after the PAR agumentation could explain, by a carbon flux in the cell inducing an osmotic reaction, the overshoot in cell volume observed for $H$. elongata. This theoretical study also stresses that, for the PAR change investigated, the observed transient maximum of $\mathrm{P}$ cell ${ }^{-1}$ can explain some of the variability in the primary production measured in natural populations.

Table 5. Hymenomonas elongata. Parameters used for simulation of cellular production before and after increase in PAR. Chla expressed as pg cell ${ }^{-1}, \mathrm{P}^{\mathrm{B}}$ max as $\mathrm{pgC} \mathrm{pg} \mathrm{Chla}^{-1} \mathrm{~h}^{-1}$ and $\alpha^{B}$ as pgC pg Chla $\left(\mu \mathrm{E} \mathrm{m} \mathrm{m}^{-2}\right)^{-1} \mathrm{~h}^{-1}$

\begin{tabular}{|lccc|}
\hline & Chla & $\mathrm{P}^{\mathrm{B}}{ }_{\text {max }}$ & $\alpha^{\mathrm{B}}$ \\
\hline PAR (25) & 9 & 1 & 0.02 \\
PAR (400) & 3 & 3 & 0.02 \\
K (25 $\rightarrow 400)$ & & & \\
Curve 1 & 0.04 & 0.04 & - \\
Curve 2 & 0.004 & 0.04 & - \\
Curve 3 & 0.4 & 0.004 & - \\
\hline
\end{tabular}




\section{Biochemical compounds}

The relative stability of the protein pool with regard to PAR variations is in good agreement with results obtained by several authors. Under continuous light, Chan (1978) reported an important variability of the Prcell $^{-1}$ for many diatoms and dinoflagellates without significant correlations with irradiance levels. For Euglena gracilis, Cook (1963) demonstrated that Pr cell ${ }^{-1}$ is remarkably constant under different saturating light intensities. Pr cell ${ }^{-1}$ decreased only when PAR is close to the compensation point. Under 'white light' (tungsten filament), Gostan et al. (1986) observed that the protein doubling efficiency (defined as the ratio of protein doubling rate to light quanta absorbed by the cells) is not affected when Chaetoceros protuberans is subjected to a PAR regime that limits the growth to $50 \%$ of the maximum rate. These observations suggest that, in spite of the direct or indirect role exerted by photosynthesis on all cellular synthesis, Pr cell ${ }^{-1}$ remains relatively independent of PAR variations. This is in agreement with Morris (1980). Significant reduction in $\mathrm{Pr}$ cell ${ }^{-1}$ is observed only at very low energetic levels that cannot sustain positive net growth.

According to Craigie (1974), in Haptophyceae carbon is stored in a vacuole, preferentially in the form of the polysaccharide chrysolaminaran (Lee 1980), which
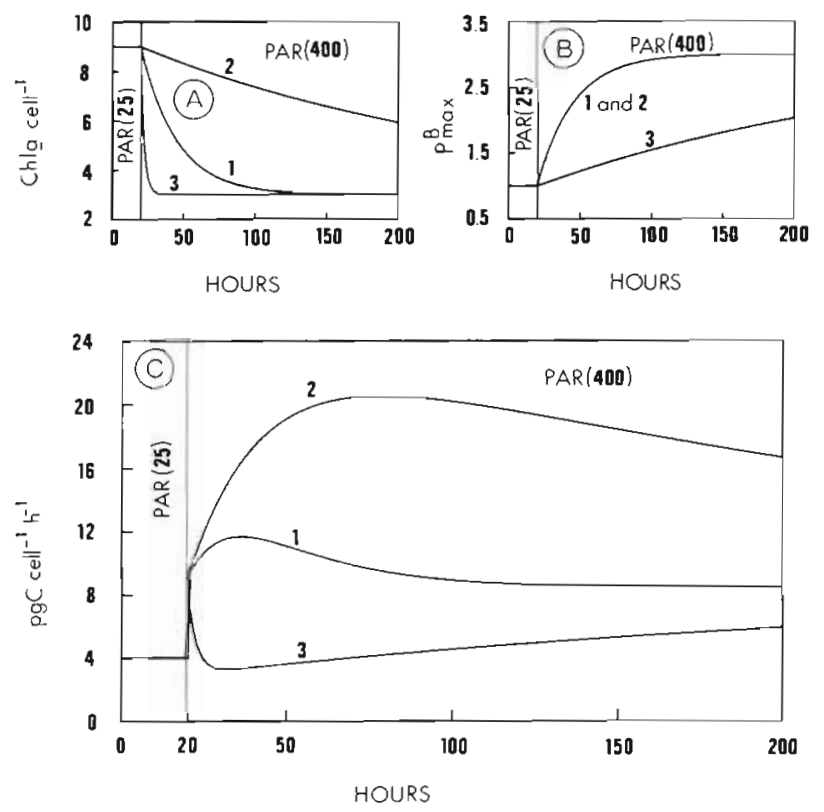

Fig. 3. Hymenomonas elongata. Theoretical approach to cellular production during a transient phase following a change in irradiance from PAR(25) to PAR(400). (A) Changes in Chla cell ${ }^{-1}$ with 3 different kinetic constants $(B)$ changes in $P_{\text {max }}^{\mathrm{B}}$ with 2 kinetic constants; (C) changes in cellular production in accordance with changes in Chla cell ${ }^{-1}$ and $\mathrm{P}^{\mathrm{B}} \max$ (curves numbered as those for Chla cell ${ }^{-1}$ and $\mathrm{P}_{\text {max }}^{\mathrm{B}}$ ). Values used in simulations are listed in Table 5 is the principal constituent of the soluble sugar (Ss) fraction. Varrum \& Myklestad (1984) showed that the chrysolaminaran pool is not affected by a PAR reduction. Inversely, Handa (1969) and Craigie (1974) demonstrated that chrysolaminaran is a photosynthetic storage material, synthesized and accumulated during the day and used in respiration at night. Our results agree with this last observation since sugar cellular pools were strongly affected (especially for Hymenomonas elongata) by the change from PAR(400) to PAR(25). However, comparison of the Ss/St ratio for Isochrysis galband, under the 2 light regimes (Table 4) shows that the pool of insoluble sugars can also be used when PAR is limiting. In this species lipid may also be a complementary form of carbon storage (Li/Pr ratio; Table 4).

Chan (1978) showed that variability in cellular responses to PAR modifications in a monospecific population is comparable to the variability between different species. Comparison of results for both haptophyceae supports this observation. Following a change in light intensity from PAR(400) to PAR(25), Hymenomonas elongata showed a marked reduction in cell volume (Table 2) as well as a total consumption of soluble sugars (Table 3 ) and a reduction in the Li/Pr ratio (Table 4). Isochrysis galbana, on the other hand, did not exhibit such variations. Nevertheless, at each irradiance level cellular caloric contents normalized to cell biovolume (Table 4) are remarkably identical for both algae. Thus the conversion efficiency of extracellular into intracellular energy seems to be equal for both algae at both irradiances in spite of the differences in biochemical composition and the distinct adaptive strategies to PAR modifications.

When cells were exposed to PAR(400) for a second time, carbon compounds in Hymenomonas elongata did not recover their initial concentration after $200 \mathrm{~h}$ at this irradiance. $H$. elongata thus seems to re-adapt very slowly to PAR(400) after exposure to low irradiances, if at all. This observation suggests that modifications in irradiance may be responsible for physiological stresses (observed for cell volume evolution) that are different for different variables, and which can last more than 1 wk as reported by Perry et al. (1981). The physiological stability of natural populations subjected to continuous irradiance perturbations is not evident from our observations.

In support of this proposal, Fig. 4 shows the adaptation state of algal biochemical ratios that may occur with regard to their kinetic constants and the time after PAR change. Since metabolic rates of organisms are inversely related to their size, this suggests that the adaptation rates of biochemical composition are also inversely related to the cell volumes, as observed for the 2 species investigated here. Consequently, a well- 


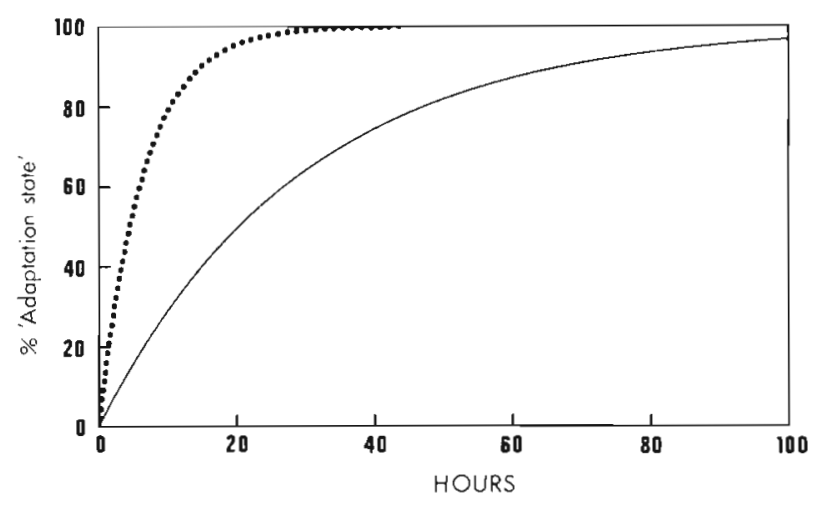

Fig. 4. Hymenomonas elongata and Isochrysis galbana. Adaptation of biochemical ratios in relation to kinetic constants and time elapsed after a change from PAR(400) to PAR(25). Ordinate: percentage of adaptation, $100 \%=$ completely adapted to PAR(25). Solid line: $\mathrm{C} / \mathrm{N}$ ratio for $H$. elongata; dotted line: $\mathrm{St} / \mathrm{Pr}$ ratio for $I$. galbana

defined duration of PAR variation can influence the biochemical composition of natural phytoplanktonic populations according to the size of the species present. For secondary producers, these changes are particularly significant. Whereas large phytoplanktonic species can filter some irradiance perturbations of high frequency, the small species which cannot do this may represent a qualitatively more unstable food source. This proposal should be compared with the comments of Cuhel et al. (1984) who suggested that many zooplanktonic organisms which migrate to the surface at night, find protein-enriched (and also glucid-poor) food, and in this way increase their assimilation efficiencies.

This study has shown that biochemical composition and cell volume of both algae investigated are sensitive to changes in PAR. Amplitude and rate of the responses can differ between species. With regard to the natural environment, biochemical composition should influence the growth of the secondary producers (Scott 1980), while changes in cell volume affects the rate of sinking (Smayda 1970, Laws 1975). However, PAR variations in the sea are not as regular as they are in controlled laboratory experiments, and steady state conditions do not exist in the ocean (e.g. Jannasch 1974). Further studies of transient states are thus necessary to understand the processes which occur over very short time scales. For this reason, the concept of the kinetic constant is essential; it may permit a comparison of different species or populations. In this way it may be possible to determine the time scales in which irradiance perturbations influence phytoplanktonic populations, and finally induce a complete adaptation, i.e. a modification of their species-specific composition.
Acknowledgements. We thank L. Legendre and R. G. Barlow for critical reviews of this manuscript. We also thank $R$. Fenaux and G. Malara for help in the use of the culture system, and Robert Charra for technical assistance.

\section{LITERATURE CITED}

Aaronson, S. (1980). Descriptive biochemistry and physiology of the Crysophyceae (with some comparisons to Prymnesiophyceae). In: Levandowsky, M., Hutner, S. H. (ed.) Biochemistry and physiology of protozoa, Vol. III. Academic Press, New York, p. 117-169

Ahmad, I., Hellebust, J. A. (1985). Osmoregulation in the euryhaline flagellate Brachimonas submanina (Chlorophyceae). Mar. Biol. 87: 245-250

Barnes, H., Blackstock, J. (1973). Estimation of lipids in marine animals and tissue: detailed investigation of the sulphophosphovanillin method for 'total' lipids. J. exp. mar. Biol. Ecol. 12: 103-118

Bligh, E. G., Dyer, W. J. (1959). A rapid method of total lipid extraction and purification. Can. J. Biochem. Biophys. 37 : 911-917

Chan, A. T. (1978). Comparative physiological study of marine diatoms and dinoflagellates in relation to irradiance and cell size. I. Growth under continuous light. J. Phycol. 14: $396-402$

Conway, G. R., Glass, N. R., Wilcox, J. C. (1970). Fitting nonlinear models to biological data by Marquardt's algorithm. Ecology 51: 503-507

Cook, J. R. (1963). Adaptations in growth and division in Euglena effected by energy supply. J. Protozool. 10: $436-444$

Craigie, J. S. (1974). Storage products. In: Stewart, W. D. P. (ed.) Algal physiology and biochemistry. Univ of California Press, Berkeley, p. 206-235

Cuhel, R. S., Ortner, P. B., Lean, D. R. S. (1984). Night synthesis of protein by algae. Limnol. Oceanogr. 29: 731-744

Dor, I. (1985). Long-lasting effect of dilution on the cell volume, motility, division rate and vertical distribution of Dunaliella parva Lerche. J. exp. mar. Biol. Ecol. 91: 183-197

Dubois, M. K., Gilles, A., Hamilton, J. K., Rebers, P. A., Smith, F. (1956). Colorimetric method for determination of sugars and related substances. Analyt. Chem. 28: 350-356

Falkowski, P. G. (1980). Light-shade adaptation in marine phytoplankton. In: Falkowski, P. G. (ed.) Primary productivity in the sea. Plenum Press, New York, p. 99-119

Falkowski, P. G. (1983). Light-shade adaptation and vertical mixing of marine phytoplankton: a comparative field study. J. mar. Res. 41: 215-237

Falkowski, P. G. (1984). Kinetics of adaptation to irradiance in Dunaliella tertiolecta. Photosynthetica 18: 62-68

Falkowski, P. G., Owens, T. G. (1980). Light-shade adaptation. Two strategies in marine phytoplankton. Plant Physiol, 66 : 592-595

Fenaux, R., Malara, G., Claustre, H. (1985). A turbidostat driven and controlled by microcomputer. Aquaculture 48: 91-95

Gallagher, J. C., Alberte, R. S. (1985). Photosynthetic and cellular photoadaptive characteristics of three ecotypes of the marine diatom Skeletonema costatum (Grev.) Cleve. J. exp. mar. Biol. Ecol. 94: 233-250

Gostan, J., Lechuga-Deveze, C., Lazzara, L. (1986). Does blue light affect the growth of Chaetoceros protuberans (Bacillariophyceae)? J. Phycol. 22: 63-71 
Guillard, R. R. L., Ryther, J. H. (1962). Studies of marine plankton diatoms. I. Cyclotelia nana Husted and Detonula confervacea (Cleve) Gran. Can. J. Microbiol. 8: 229-239

Handa, N. (1969). Carbohydrate metabolism in the marine diatom Skeletonema costatum. Mar. Biol. 4: 208-214

Jannasch, H. W. (1974). Steady state and the chemostat in ecology. Limnol. Oceanogr 19: 715-720

Jeffrey, S. W. Humphrey, G. F. (1975). New spectrophotometric equations for determining chlorophylls $a, b, c_{1}$ and $c_{2}$ in higher plants, algae and natural phytoplankton. Biochem. Biophys. Pflanz. 167: 191-194

Jørgensen, E. G. (1964). Adaptation to different light intensities in the diatom Cyclotella meneghiniana Kütz. Physiologia pl. 17. 136-145

Laws, E. A. (1975). The importance of the respiration losses in controlling the size distribution of marine phytoplankton. Ecology 56: 419-426

Lee, R. E. (1980). Prymnesiophyceae. In: Lee, R. E. (ed.) Phycologie. Cambridge Univ. Press, Cambridge, p. $155-172$

Lowry, O. H., Rosebrough, N. J., Farr, A. L., Randall, R. J. (1951). Protein measurement with the Folin phenol reagent. J. biol. Chem. 193: 265-267

Malara, G., Charra, R. (1972a). Dosage des protéines particulaires du phytoplancton selon la méthode de Lowry. Note de travail No. 5, station zoologique, Villefranche sur mer

Malara, G., Charra, R. (1972b). Dosage des glucides particulaires du phytoplancton selon la méthode de Dubois. Note de travail No.6, station zoologique, Villefranche sur mer

Mortis, I. (1980). Paths of carbon assimilation in marine phytoplankton. In: Falkowski, P. G. (ed.) Primary productivity in the sea. Plenum Press, New York, p. 139-159

Morris, I. (1981). Photosynthesis products, physiological state, and phytoplankton growth. In: Platt, T (ed.) Physiological bases of phytoplankton ecology. Can. Bull. Fish. Aquat. Sci. 210: 83-102

Perry, M. J., Talbot, M. C., Alberte, R. S. (1981). Photoadaptation in marine phytoplankton: response of the photosynthetic unit. Mar. Biol. 62: 91-101

Platt, T., Denman, K. L., Jassby, A. D. (1977). Modeling the productivity of phytoplankton. In: Goldberg, E. D. (ed.) The sea, Vol. VI. Wiley, New York, p. 807-856

Post, A. F., Dubinsky, Z., Wyman, K., Falkowski, P. G. (1984) Kinetics of light-intensity adaptation in a marine planktonic diatom. Mar Biol. 83: 231-238
Prezelin, B. B., Sweeney, B. M. (1978). Photoadaptation of photosynthesis in Gonyaulax polyedra. Mar Biol. 48: 27

Prosser, C. L., Brown, F. A. (1961). Comparative animal physiology, 2nd edn. Saunders, Philadelphia

Raps, S., Wyman, K., Siegelman, H. W., Falkowski, P. G (1983). Adaptation of the cyanobactenum Microcystis aeruginosa to light intensity. Plant Physiol. 72: 829-832

Redalje, D. G., Laws, E. A. (1983). The effects of environmental factors on growth and the chemical and biochemical composition of marine diatoms. I. Light and temperature effects. J. exp. mar Biol. Ecol. 68: 59-79

Reed, R. H., Stewart, W. D. P. (1985). Osmotic adjustment and organic solute accumulation in unicellular cyanobacteria from freshwater and marine habitats. Mar Biol. 88: 1-9

Riisgård, H. U., Nørgård Nielsen, K., Sogaard-Jensen, B. (1980). Further studies on volume regulation and effects of copper in relation to $\mathrm{pH}$ and EDTA in the naked marine flagellate Dunaliella marina. Mar. Biol. 56: 267-276

Scott, J. M. (1980). Effect of the growth rate of the food alga on the growth/ingestion efficiency of a marine herbivore. J. mar. biol. Ass. U.K. 60: 681-702

Senger, H., Fleischhacker, P. H. (1978). Adaptation of the photosynthetic apparatus of Scenedesmus obliquus to strong and weak light conditions. I. Differences in pigments, photosynthetic capacity, quantum yield and dark respiration. Physiologia pl. 43: 35-42

Smayda, T. J. (1970). The suspension and sinking of phytoplankton in the sea. Oceanogr. mar. Biol. A. Rev. 8: $353-414$

Steemann Nielsen, E., Hansen, V, K. (1959). Light adaptation in marine phytoplankton populations and its inter-relation with temperature. Physiologia pl. 12: 353-370

Steemann Nielsen, E., Jørgensen, E. G. (1968). The adaptation of plankton algae. I. General part. Physiologia pl. 21: $401-413$

Talling, J. F. (1957). Photosynthetic characteristics of some freshwater plankton diatoms in relation to underwater radiation New Phytol. 56: 29-50

Terry, K. L., Hirata, J., Laws, E. A. (1983). Light-limited growth of two strains of the marine diatom Phaeodactylum tricornutum Bohlin: chemical composition, carbon partitioning and the diel periodicity of physiological processes. J. exp. mar Biol. Ecol. 68: 209-227

Vårum, K. M, Myklestad, S. (1984). Effects of light, salinity and nutrient limitation on the production of b-1,3-D-glucan and exo-D-glucanase activity in Skeletonema costatum (Grev.) Cleve. J. exp. mar. Biol. Ecol. 83: 13-25 